\title{
COMPARISON OF FREQUENCY OF SEROMA FORMATION IN FLAP FIXATION VERSUS CONVENTIONAL CLOSURE AFTER MODIFIED RADICAL MASTECTOMY.
}

\footnotetext{
1. MBBS, FCPS (General Surgery) Assistant Professor Surgery Allied Hospital, Faisalabad.

Correspondence Address: Dr. Muhammad Dilawaiz Mujahid Department of Surgery Allied Hospital, Faisalabad. dilawaiz786@hotmail.com

Article received on: 06/04/2019 Accepted for publication: 03/03/2020

\begin{abstract}
Muhammad Dilawaiz Mujahid', Muneeza Zubair ${ }^{2}$, Tayyab Ahsan Tanvir ${ }^{3}$, Jaweria Masood ${ }^{4}$
\end{abstract}
\begin{abstract}
Seroma formation is a known complication after any surgery where excessive dissection of subcutaneous tissue leads to disruption of lymphatic channels. Seroma formation, its sequelae and frequent visits to doctor for their management are a common source of discomfort for patients. Objectives: Comparison of frequency of seroma formation after flap fixation versus convetional closure after modified radical mastectomy. Study Design: Randomized control trial. Setting: Department of Surgery, Allied Hospital Faisalabad. Period: May 1, 2016 to October 31, 2016. Material \& Methods: After permission from Hospital ethics committee and informed consent from patients, 70 patients were randomly divided into two groups (35 participants in each group). Findings were noted and data was analyzed statistically. Results: It was observed that incidence of seroma formation following modified radical mastectomy was lower with flap fixation technique (14.29\%) as compared to conventional closure of wound margins (42.86\%). Conclusion: Flap fixation technique is better approach compared to conventional method to prevent seroma formation.
\end{abstract}

Key words: $\quad$ Breast Carcinoma, Flap Fixation Technique, Modified Radical Mastectomy, Seroma Formation.

Article Citation: Mujahid MD, Zubair M, Tanvir TA, Masood J. Comparison of frequency of seroma formation in flap fixation versus conventional closure after modified radical mastectomy. Professional Med J 2020; 27(5):907-909.

DOI: 10.29309/TPMJ/2020.27.05.3526

\section{INTRODUCTION}

For several decades breast cancer has been second leading cause of death in women worldwide. According to some estimates 1 in 9 Pakistani women develop breast cancer in their life. In fact Pakistan has the highest incidence of breast cancer in Asia. ${ }^{1}$ Majority of patients have to undergo modified radical mastectomy to ensure the effective removal of malignant cells. Seroma, a collection of fluid comprised of blood and lymph, is a common complication after mastectomy. ${ }^{2}$

The pathogenisis of its formation is not fully understood but it is believed to be inflammatory exudates released due to fibrinolytic activity in response to inflammation, wound healing and surgical trauma. ${ }^{3,4}$ Various studies report incidence of seroma formation from 15 to $81 \% .^{5}$

It is a source of significant morbidity, health care costs and hospitalization. Different approaches have been introduced to improve reduction of post operative seroma formation. It was noticed during other surgical techniques that reduction in dead space can help decrease post operative incidence of seroma formation. ${ }^{6}$

The rationale of this study was to find a better surgical technique with decreased risk of seroma formation and improve early recovery. Flap fixation method was found to be a better surgical technique and the authors recommend its implementation in regular practice.

\section{MATERIAL \& METHODS}

This randomized control trial was carried out in General Surgery units of Allied Hospital Faisalabad. The duration of study was 6 months from May 1, 2016 to October 31, 2016. Permission was taken from hospital's ethical committee. Female patients aged 25 to 60 years with diagnosed case of breast carcinoma were included in the study after an informed consent. 
Seventy patients were included in the study and were divided into two equal groups randomly, each group contained 35 participents. Patients in Group A underwent flap fixation method while conventional closure method was used for Group B (control group). Progress of patients was followed in ward and via outpatient department. Collected data was analyzed statistically.

Flap fixation method was performed as described by Almond et al. in $2010 .{ }^{7}$ It involves the suturing of skin flaps to pectorals muscles with absorbable sutures (vicryl 3.0). Depending upon the size of skin flap suturing is done in two or three rows and each suture is placed about $3 \mathrm{~cm}$ apart. Careful placement of sutures should not produce skin dimpling.

The purpose of this technique is to decrease dead space for seroma formation. However, closure of axillary dead space is not recommended.

\section{RESULTS}

A total of 70 patients were randomly divided in two equal groups. Group A underwent flap fixation technique and Group B underwent conventional method of flap closure. Included patients were 25-60 years old. Patients with age ranging from $25-40$ years were $22.71 \%(n=9)$ and $22.86 \%(n=8)$ in Group A and B respectively while 41-60 year old patients were $74.29 \%(n=26)$ in Group A and $77.14 \%(n=27)$ in Group B. Groups were compared for incidence of seroma formation, Group A (14.29\%) had lower incidence of seroma formation as compared to Group B (42.86\%). A p value of 0.008 showed a significant difference in two groups.

\begin{tabular}{|c|c|c|c|c|}
\hline \multirow{2}{*}{$\begin{array}{c}\text { Age } \\
\text { (in years) }\end{array}$} & \multicolumn{2}{|c|}{$\begin{array}{c}\text { Group-1 } \\
\text { (n=35) }\end{array}$} & \multicolumn{2}{c|}{$\begin{array}{c}\text { Group-2 } \\
\text { (n=35) }\end{array}$} \\
\cline { 2 - 5 } & $\begin{array}{c}\text { No. of } \\
\text { Patients }\end{array}$ & $\%$ & $\begin{array}{c}\text { No. of } \\
\text { Patients }\end{array}$ & $\%$ \\
\hline $25-40$ & 9 & 25.71 & 8 & 22.86 \\
\hline $41-60$ & 26 & 74.29 & 27 & 77.14 \\
\hline Total & 35 & 100 & 35 & 100 \\
\hline Mean+SD & $46.03+7.94$ & $47.51 \pm 8.25$ \\
\hline
\end{tabular}

\begin{tabular}{|c|c|c|c|c|}
\hline \multirow{2}{*}{$\begin{array}{c}\text { Seroma } \\
\text { Formation }\end{array}$} & \multicolumn{2}{|c|}{$\begin{array}{c}\text { Group-1 } \\
(n=35)\end{array}$} & \multicolumn{2}{|c|}{$\begin{array}{c}\text { Group-2 } \\
(n=35)\end{array}$} \\
\hline & $\begin{array}{l}\text { No. of } \\
\text { Patients }\end{array}$ & $\%$ & $\begin{array}{l}\text { No. of } \\
\text { patients }\end{array}$ & $\%$ \\
\hline Yes & 5 & 14.29 & 15 & 42.86 \\
\hline No & 30 & 85.71 & 20 & 57.14 \\
\hline Total & 35 & 100 & 35 & 100 \\
\hline \multicolumn{5}{|c|}{$\begin{array}{l}\text { Table-II. Comparison of seroma formation in flap } \\
\text { fixation versus conventional closure after modified } \\
\text { radical mastectomy }(n=70) \\
\text { P value }=0.008\end{array}$} \\
\hline
\end{tabular}

\section{DISCUSSION}

Seroma formation is commonly observed following surgeries where excessive dissection is performed. It can further complicate wound healing by promoting infection and skin necrosis. Overall it is a significant source of discomfort for patient and a burden on health care system. Patrek et al. described that frequency of seroma formation was directly associated with extent of axillary dissection. ${ }^{8}$ However separate studies by Gonzalez et al. ${ }^{9}$ and Hashemi et al. ${ }^{10}$ reported the type of surgery and extent of dissection was the only statistically significant factor influencing seroma formation. Age of patient, size of tumor, comorbidties and neoadjuvant chemotherapy had no correlation with seroma formation. Purushotham et al. noticed reduced seroma formation and improved outcomes in patients who underwent flap fixation technique. He also observed that patient did not require placement of drains with this technique. ${ }^{11}$

The purpose of this study was to present a better surgical technique for reduction of seroma formation. Flap fixation technique was first described by Halsted in 1913. ${ }^{12}$ It was observed that incidence of seroma formation following modified radical mastectomy was lower with flap fixation technique (14.29\%) as compared to conventional closure of wound margins (42.86\%). The results were comparable to a similar study where significant reduction in seroma formation was noticed clinically $(p=0.028)$ and ultrasonographically $(p=0.047)$ following flap fixation technique (10\%) compared to the control group (40\%). ${ }^{2}$ A similar study was carried out by Van Bastelaar et al. they included 92 patients in 
flap fixation group while 88 patients underwent conventional closure. Seroma formation in flap fixation group was $35.9 \%$ as compared to $59.1 \%$ in conventional group. ${ }^{13}$ Another study by Sakkary was carried out in 2012 showed significantly lower seroma formation in flap fixation group $(p=0.028)$. He also noticed less complications such as cellulitis and flap necrosis in flap fixation group as compared to conventional group. ${ }^{14}$

\section{CONCLUSION}

Seroma formation was less frequently observed in flap fixation technique than conventional wound closure method.

Copyright $@ 03$ Mar, 2020.

\section{REFERENCES}

1. $\mathrm{Li} \mathrm{Cl}$, Uribe DJ, Daling JR. Clinical characteristics of different histologic types of breast cancer. $\mathrm{Br} \mathrm{J}$ Cancer 2005; 93:1046.

2. Srivastava V, Basu S, Shukla VK. Seroma formation after breast cancer surgery: what we have learned in the last two decades. J Breast Cancer. 2012; 15:37380.

3. Pogson CJ, Adwani A, Ebbs SR. Seroma following breast cancer surgery. Eur J Surg Oncol. 2003; 29:711-17.

4. Oertli D. Axillary lymphadenectomy. Chirurg. 2000; 78:196-202.

5. Sakkary MA. The value of mastectomy flap fixation in reducing fluid drainage and seroma formation in breast cancer patients. World J Surg Oncol. 2012; 10:8.
6. Eichler C, Fischer P, Sauerwald A, Dahdouh F, Warm $M$. Flap adhesion and effect on postoperative complication rates using Tissuglu ${ }^{\circledR}$ in mastectomy patients. Breast Cancer. 2016 May 1;23(3):486-90.

7. Almond LM. Flap anchoring following primary breast cancer surgery facilitates early hospital discharge and reduces costs. Breast Care. 2010; 5:97-101.

8. Petrek J, Peters M, Nori S, Knauer C, Kinne D, Rogatko A. Axillary lymphadenectomy. A prospective, randomized trial of $\mathbf{1 3}$ factors influencing drainage, including early or delayed arm mobilization. Arch Surg. 1990; 125:378-82.

9. Gonzalez EA, Saltzstein EC, Riedner CS, Nelson BK. Seroma formation following breast cancer surgery. Breast J. 2003; 9:385-8.

10. Hashemi E, Kaviani A, Najafi M, Ebrahimi M, Hooshmand $\mathrm{H}$, Montazeri A. Seroma formation after surgery for breast cancer. World J Surg Oncol. 2004; 2:44.

11. Purushotham AD, McLatchie E, Young D, George WD, Stallard S, Doughty J, Brown DC, Farish C, Walker A, Millar K, Murray G. Randomized clinical trial of no wound drains and early discharge in the treatment of women with breast cancer. Br J Surg. 2002; 89:286292.

12. Halsted WS. Developments in skin grafting operation for cancer of the breast. JAMA 1913; 60:416.

13. van Bastelaar J, Beckers A, Snoeijs M, Beets G, \& Vissers $Y$. Flap fixation reduces seroma in patients undergoing mastectomy: A significant implication for clinical practice. World J Surg Oncol, 2016; 14: 66.

14. Sakkary MA. The value of mastectomy flap fixation in reducing fluid drainage and seroma formation in breast cancer patients. World J Surg Oncol. 2012; 10, 8.

\begin{tabular}{|c|c|c|c|}
\hline \multicolumn{4}{|c|}{ AUTHORSHIP AND CONTRIBUTION DECLARATION } \\
\hline Sr. \# & Author(s) Full Name & Contribution to the paper & Author(s) Signature \\
\hline 1 & M. Dilawaiz Mujahid & Script writing, Data collection. & Mil \\
\hline 2 & Muneeza Zubair & $\begin{array}{l}\text { Data collection, Reference } \\
\text { Search. }\end{array}$ & lhuzger \\
\hline 3 & Tayyab Ahsan Tanvir & $\begin{array}{l}\text { Data collection, Reference } \\
\text { search. }\end{array}$ & Tapylthance \\
\hline 4 & Jaweria Masood & $\begin{array}{l}\text { Proof reading, Statistical } \\
\text { analysis. }\end{array}$ & Sourene \\
\hline
\end{tabular}

